\title{
PHYTOCHEMICAL AND BIOLOGICAL INVESTIGATION OF THE VOLATILE CONSTITUENTS OF NEPETA SEPTEMCRENATA EHRENB., GROWING IN EGYPT
}

\author{
Mohamed M. A. El-Hamouly and Atef A. El-Hela \\ Department of Pharmacognosy, Faculty of Pharmacy, Al-Azhar University, Nasr City, Cairo, \\ Egypt

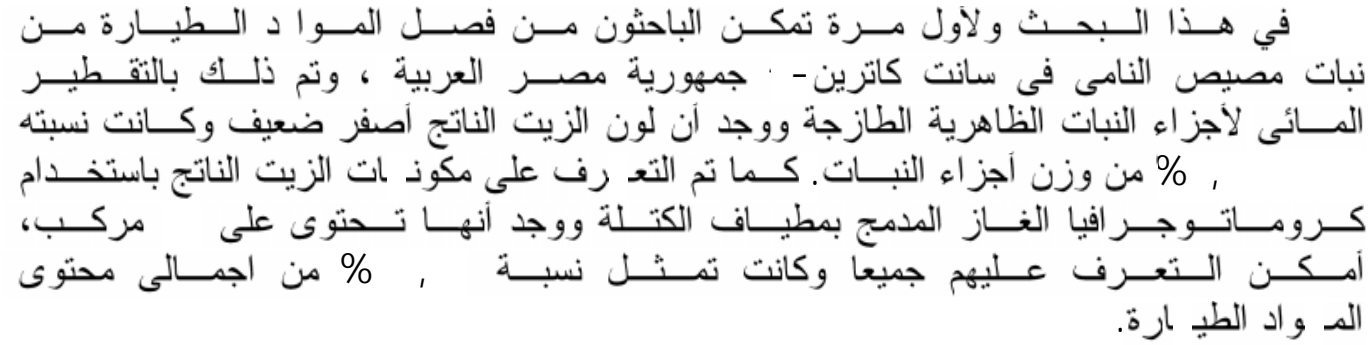

The volatile constituents of Nepeta septemcrenata Ehrenb. herb growing in Egypt were prepared by hydrodistillation of the fresh herb and analysed by GC/MS. Sixteen major compounds (represent $94.96 \%$ of total) were detected and identified. They contain ten oxygenated compounds $(70.67 \%)$ and six hydrocarbons $(24.29 \%)$. The major oxygenated compounds were 1,2 benzene-dicarboxylic acid dibutyl ester (33.16\%) and 4-methyl-2,6ditertbutyl phenol $(23.30 \% \mathrm{w} / \mathrm{w})$, while the major hydrocarbon is 4-nonyne $C_{9} H_{16}$, $(9.00 \%)$. The volatile constituents had promising antimicrobial activities against some tested microorganisms.

\section{INTRODUCTION}

Genus Nepeta, family Lamiaceae, includes 250 species of perennial plants with small crenate leaves and blue corolla with narrow long exerted tubes. ${ }^{1}$ They are of medicinal and aromatic plants widely grown in Mediterranean countries. ${ }^{2} \quad$ Nepeta septemcrenata Ehrenb (Figure 1) is an erect slender plant with branches at base. Leaves are oppositely alternated, ovate with crenate or slightly dentate margins. ${ }^{1}$ This plant was found in Sant Cathrine (Sinai, Egypt). ${ }^{1}$ It was reported that Nepeta plants were prepared as tea and used in traditional medicine as anthelmintics, febrifuges, expectorants, to treat bronchitis, bites, stings of and scorpions. ${ }^{3}$ They have antispasmodic, astringent properties, ${ }^{3}$ cardiotonic ( $N$. ciliaris), diaphoretic, skin diseases( $\boldsymbol{N}$. hindostana) and anticatarrhal $(\boldsymbol{N}$. hederacea). ${ }^{4}$ Several Nepeta species are characterized by the presence of essential oil..$^{5-}$
11. An isopimarane type diterpene and 7-Omethylapigenin were isolated from the ethanol extracts of Nepeta septimcrenata Ehrenb herb. ${ }^{12}$ Nothing was found in literature, so far, concering the chemical composition of the volatile constiuents of Nepeta septemcrenata Ehrenb herb.

\section{EXPERIMENTAL}

\section{Plant material}

Nepeta septemcrenata Ehrenb (aerial parts) were collected on August, 2002 from wadi gebal in Sant cathrin (Sinai) and kindly identified by the late Prof. Dr. Nabil AlHadidi, Prof. of Plant Taxnomy, Department of Botany, Faculty of Science, Cairo University. A voucher herbarium specimen had been deposited in the Museum of Medicinal Plants, Department of Pharmacognosy, Faculty of Pharmacy Al-Azhar University, Cairo (Egypt). 


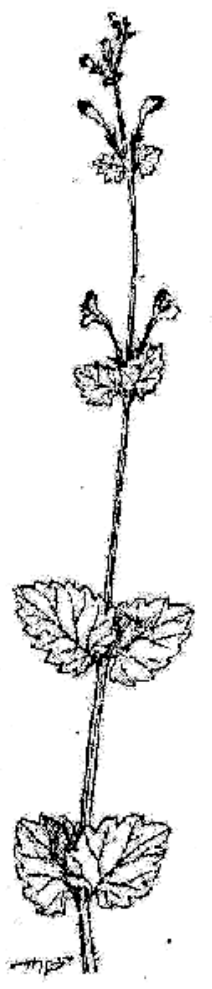

Fig. 1: Nepeta septemcrenata Ehrenb. Herb.

\section{Preparation of the volatile constituents}

The volatile constituents were prepared from the fresh aerial parts of Nepeta septemcrenata Ehrenb. by hydrodistillation according to E.P. (1984). ${ }^{13}$ The volatile constituents were extracted with diethylether and dried over anhydrous sodium sulfate. The yielded oil of Nepeta septemcrenata Ehrenb was $0.14 \% \mathrm{w} / \mathrm{w}$, yellowish green in colour and has an aromatic odour.

\section{Identification of the volatile constituents}

The prepared volatile constituents were analysed by GC using the apparatus Shimadzu GC/MS - QP 5050 A. Software Class 5000. Column: DBI, $30 \mathrm{~m}$ x $0.53 \mathrm{~mm}$ i.d, $1.5 \mu \mathrm{m}$ film thickness. Carrier gas: Helium (flow rate $1 \mathrm{ml} /$ min). Ionization mode: E.I. $(70 \quad$ ev $)$. Temperature program: $30^{\circ}$ (static for $2 \mathrm{~min}$ ) then gradually increasing (at a rate of $2 \% \mathrm{~min}$ ) up to $250^{\circ}$ (static for $5 \mathrm{~min}$ ). detector (FID) temperature $280^{\circ}$. Injector temperature $280^{\circ}$. Qualitative identification of the volatile constituents was achieved by library searched data base Willey 229LIB. and by comparing their mass fragmentation patterns with those of the available published data. ${ }^{14-15}$
Quantitative estimation of the the volatile constituents was determined by computerized peak area measurements using internal normalization method.

\section{Antimicrobial activities}

The disc agar diffusion technique ${ }^{16}$ was used for testing antimicrobial activity of the volatile constituents against certain Gram +ve, Gram -ve bacteria and fungi. Pure strains of Staphylococcus aureus ATCC 6538, Bacillus subtilis ATCC 6633, E. coli ATCC 25922, Pseudomonas aeruginosa ATCC 27853, as well as Aspergillus niger, Penicillium marneffei, Syncephalastrum raccemosum and Candida albicans were kindly supplied from Staff members of the Microbiology Depertment, Faculty of Pharmacy, Al-Azhar University, Nasr City, Cairo, Egypt. Four mm Discs (4 mm each) of filter paper (Whatmann No. 3) were impregnated in volatile oil solution ( $0.1 \mathrm{~g} \%$ in diethyl ether) and placed on the surface of nutrient agar, and sabaroud's dextrose agar. seeded with tested microorganisms. Discs impregnated in diethyl ether was used as a negative control in each plate. The plates were incubated at $37^{\circ}$ for 24 hours and at $25^{\circ}$ for 72 hours to investigate the antibacterial and antifungal activities, respectively. Chloramphenicol (5 $\mu \mathrm{g} / \mathrm{discs}$ ) and Terbinafin $(4.5 \mu \mathrm{g} /$ disc $)$ were used as positive standards

\section{RESULTS AND DISCUSSION}

Phytochemical screening of Nepeta septemcrenata Ehrenb herb revealed the presence of phenolic and terpenoid compounds. ${ }^{(17)}$ The volatile constituents of Nepeta septemcrenata Ehrenb herb (50 g) was prepared by hydrodistillation using E.P 1984 apparatus. The obtained oil is yellowish green in colour, heavier than water and with characteristic odour. It yielded $0.14 \% \mathrm{w} / \mathrm{w}$ of volatile oil, soluble in pet.-ether, ether, chloroform, ethyl acetate and alcohol. The components of this oil were detected by silica gel TLC developed in benzene and showed several spots, some of them acquired blue colour with $\mathrm{FeCl}_{3}$ indicating their phenolic nature $^{(17) .}$ Further investigation by TLC was impossible due to lack of authentic samples. GC/MS of the volatile components revealed the 
presence of 16 peaks (represent $94.96 \%$ of total, Table 1) were identified. They could be classified to oxygenated (10 compounds) and non oxygenated (6 compounds) representing 70.67 and $24.29 \%$, respectively. The most abundant one of the oxygenated derivatives is 1,2-benzenedicarboxylic acid dibutyl ester $\left(\mathrm{R}_{\mathrm{t}}\right.$ $\left.83.02 \mathrm{~min}^{-1}\right)$ and 4-methyl-2,6ditertbutylphenol $\left(\mathrm{R}_{\mathrm{t}}\right.$ 57.76), representing 33.16 and $23.30 \% \mathrm{w} / \mathrm{w}$, respectively

Identification of the the volatile constituents were done on the bases of matching data with Wiley 229 LIB. library search system and comparison of mass spectra fragmentation patterns with those reported in the available literature. ${ }^{14,15,18-21}$ The antimicrobial screening of the volatile constituents of the aerial parts of Nepeta septemcrenata Ehrenb. growing in Egypt (Table 2) revealed that they have a significant antimibacterial effect against Staphylococcus aureus, Bacillus subtilis and Pseudomonas aerugenosa, but they are not active against $E$. coli. Compounds responsible for antimicrobial activities of Nepeta septemcrenata in the volatile constituents will be studied in detail in future, on availability of plant samples. These volatile constituents could be used for treatment of skin infections caused by Staphylococcus aureus or Pseudomonas aerugenosa.

Table 1: GC/MS data of the volatile constituents of Nepeta Septemcrenata Ehrenb.

\begin{tabular}{|c|c|c|c|c|c|}
\hline $\mathrm{R}_{1}$ & $\%$ & $\mathrm{M}^{+}$ & B.p. & Other fragments* & Name of Compound \\
\hline \multicolumn{6}{|c|}{ A. Oxygenated Volatile constituents } \\
\hline 28.17 & 0.53 & 170 & 59 & $43,55,41,67,94$ and 95 & Linalol oxide \\
\hline 36.03 & $\mathrm{~T}$ & 172 & 60 & $59,43,73,71$ and 94 & Decanoic acid \\
\hline 47.11 & 5.45 & 152 & 53 & $82,54,110,81,41,67,109$ and 124 & $\mathrm{C}_{10} \mathrm{H}_{16} \mathrm{O}, \quad$ Thujone \\
\hline 51.79 & 3.25 & 154 & 41 & $67,81,113$ and 153 & 2-Decyn-1-ol \\
\hline 57.76 & 23.3 & 220 & 205 & $\begin{array}{c}41,57,220,91,77,105,115,145,15 \\
5 \text { and } 177 \\
\end{array}$ & $\begin{array}{l}\mathrm{C}_{15} \mathrm{H}_{24} \mathrm{O}, \quad 4-\mathrm{Me}-2,6- \\
\text { Ditertbutylphenol }\end{array}$ \\
\hline 65.65 & 1.34 & 222 & 41 & $151,93,95,81,107$ and 111 & $\mathrm{C}_{15} \mathrm{H}_{26} \mathrm{O}, \quad$ Widdrol \\
\hline 83.02 & 33.16 & 278 & 149 & $41,76,104,205$ and 223 & $\begin{array}{l}\mathrm{C}_{16} \mathrm{H}_{22} \mathrm{O}_{4}, \quad \text { 1,2-benzene- } \\
\text { Dicarboxylicacid dibutyl ester }\end{array}$ \\
\hline 86.76 & 3.64 & 256 & 41 & $56,60,73,83$ and 129 & $\mathrm{C}_{16} \mathrm{H}_{32} \mathrm{O}_{2}$, Hexadecanoic acid \\
\hline 95.38 & $\mathrm{~T}$ & 282 & 41 & $55,69,98,83,111,147$ and 127 & $\mathrm{C}_{18} \mathrm{H}_{34} \mathrm{O}_{2}, \quad$ Oleic acid \\
\hline 110 & $\mathrm{~T}$ & 390 & 149 & $167,57,43,71,279$ & $\begin{array}{l}\mathrm{C}_{24} \mathrm{H}_{38} \mathrm{O}_{4}, 1,2 \text {-benzene- } \\
\text { Dicarboxylic acid, bis(2- } \\
\text { Ethylhexyl) ester }\end{array}$ \\
\hline Total & 70.67 & & & & \\
\hline \multicolumn{6}{|c|}{ B. Volatile Hydrocarbon Constituents } \\
\hline 36.66 & 0.27 & 138 & 41 & $81,65,95$ and 123 & $\begin{array}{l}\mathrm{C}_{10} \mathrm{H}_{18}, \quad 3,5 \text {-Octadiene-2,7- } \\
\text { dimethyl }\end{array}$ \\
\hline 41.13 & 5.14 & 110 & 67 & $8,1.41$ and 95 & $\mathrm{C}_{8} \mathrm{H}_{14}, \quad 3$-Octyne \\
\hline 43.22 & 9.00 & 124 & 67 & 81,41 and 95 & 4-Nonyne \\
\hline 99.6 & 0.83 & 226 & 43 & 57 and 71 & $\mathrm{C}_{16} \mathrm{H}_{34}, \quad$ Hexadecane \\
\hline 103.9 & 2.36 & 254 & 43 & 57,71 and 85 & $\mathrm{C}_{18} \mathrm{H}_{38}$, 2-methyl-Pentadecane \\
\hline 108.2 & 6.69 & 269 & 43 & 57,71 and 85 & $\mathrm{C}_{21} \mathrm{H}_{44}, \quad$ n-Heneicosane \\
\hline Total & 24.29 & & & & \\
\hline
\end{tabular}

* MS fragments were arranged in a decreasing order of their intensities 
Table 2: Antimicrobial activity of the volatile constituents of Nepeta septemcrenata Ehrenb.

\begin{tabular}{||l|c|c|c|c|}
\hline \multicolumn{1}{|c|}{ Micro-organsims } & DEE & 1 & A & B \\
\hline Staphylococcus aureus. & 00 & + & ++ & 00 \\
\hline Bacillus subtilis & 00 & + & ++ & 00 \\
\hline E.coli. & 00 & 00 & ++ & 00 \\
\hline Pseudomonas aerugenosa & 00 & + & ++ & 00 \\
\hline Candida albicans & 00 & 00 & 00 & ++ \\
\hline Penicillium marneffei & 00 & 00 & 00 & ++ \\
\hline $\begin{array}{l}\text { Syncephalastrum } \\
\text { racemosum }\end{array}$ & 00 & 00 & 00 & ++ \\
\hline Aspergillusniger & 00 & 00 & 00 & ++ \\
\hline
\end{tabular}

1, volatile constituents; A, Antibacterial (+ve control, chloramphenicol); B, Antifungal (Terbinafin, +ve control); DEE, diethylether(-ve control); + , Inhibition values of 1: $5 \mathrm{~mm}$ beyond control; ++, Inhibition values of $6: 10 \mathrm{~mm}$ beyond control and $00=$ inhibition zones were not detected.

\section{Acknowledgements}

The authors are highly grateful to Dr. A. Marie, A lecturer of Plant Ecology, Department of Botany, Faculty of Science, Al-Azhar University for help in plant collection and to late Prof. Dr. Nabil Al-Hadidi, Prof. of Plant Taxonomy, Department of Botany, Faculty of Science, University of Cairo, Cairo, Egypt for plant identification

\section{REFERENCES}

1- A. M. Pagni, S. Catalano, P. 1. Cioni, C. Coppi, I. Morelli, Plantes Medicinales - etPhytotherpie, (24) 3, 203-213 (1990).

2- V. Tackholm, Student's Flora of Egypt, $2^{\text {nd }}$, Ed., Cairo Univ. Cooperative Printing Co., Beirut (1974).

3- N. Arnold, B. Bellomaria, G. Volentiri, C. Yanninou, H. J. Arnald, Plantes Medicinales-et-Phytotherpie, 26, 1, 52-63 (1993).

4- G. E. Trease, and W. C. Evans, Pharmacognosy, $14^{\text {th }}$ Ed. WB, Saundres Company ltd, London, Philadephia, and Tokyo, 48 (2001).
5- R. M. Harley, and T. Reynolds, Advances in Labiatae Science $1^{\text {st }}$ ed., Royal Botanic Gardens (1992).

6- S. Ebrahim Sajjadi, N. Ghassemi, J. Flavour-Fragrance, 14 (5) 265-267 (1999).

7- O. Tzakou, C. Harvata, E. M. Galati and R. J. Sango, Flavour-Fragrance J., 15 (2), 115-118 (2000).

8- H. D. Skaltsa, D. M. Lazari, A. E. Loukis and T. Canstantindis, Flavour-Fragrance J., 15 (2), 96-99 (2000).

9- A. Rustaiyon and K. Nnadji, FlavourFragrance. J., 14 (1), 35-37 (1999).

10- G. Kokdil, S. Kurucu and A. Yildiz, Flavour-Fragrance J., 13 (4), 333-334 (1998).

11- K. Javidnio, R. Miri, F. Safavi, A. Azarpira and A. Shafiee, FlavourFragrance J., 17 (1), 20 -22.

12- A. T. khalil, S. R. Gedara, M. F. Lahloub, A. F. Halim and M. Voehler, Phytochemistry, 44, 3, 474-478 (1997).

13- The Egyptian Pharmacopoeia, General Organization for Governmental Printing Affairs, 1984, $3^{\text {ed }}$ Ed., Cairo.

14- R. P. Adams, Identification of Essential oils by Ion Trap Mass Spectrometry, 1989, Academic Press, New York.

15- Eight Peak Index of Mass Spectra., Mass Spectrometry Data Center in Collaboration with ICI, LTD., Organic division $2^{\text {ed }}$ Ed., Vol. 1\&2 (1974).

16- R. Curickshank, J. P. Duguid, B. P. Marmon and R. H. A. Swain, Medical Microbiology, $12^{\text {th }}$ ed. (1975).

17- S. I. Balbaa, S. H. Hilal and A. Y. Zaki, Medicinal Plant Constituents, 1981, p. 247, General Organization for University and School Books.

18- A. H. Ghorab, H. M. Fadel and K. S. El Massry, Flavour-Fragrance J., 17, 306312 (2002).

19- M. M. A. El-Hamouly, H. A. Ammar and K. Awaad, Az. J. Pharm. Sci., 28, 360 (2001).

20- M. M. A. El-Hamouly and T. R. Mohamed, Az. J. Pharm. Sci., 28, 370 (2001).

21- M. M. A. El-Hamouly and M. T. Ibraheim, Alex. J. Pharm. Sci., 17 (1) 75-80 (2003). 